\title{
Global biogeography and evolution of Cuvierina pteropods
}

Alice K Burridge ${ }^{1,2^{*}}$, Erica Goetze ${ }^{3}$, Niels Raes ${ }^{1}$, Jef Huisman² and Katja T C A Peijnenburg ${ }^{1,2}$

\begin{abstract}
Background: Shelled pteropods are planktonic gastropods that are potentially good indicators of the effects of ocean acidification. They also have high potential for the study of zooplankton evolution because they are metazoan plankton with a good fossil record. We investigated phenotypic and genetic variation in pteropods belonging to the genus Cuvierina in relation to their biogeographic distribution across the world's oceans. We aimed to assess species boundaries and to reconstruct their evolutionary history.

Results: We distinguished six morphotypes based on geometric morphometric analyses of shells from 926 museum and 113 fresh specimens. These morphotypes have distinct geographic distributions across the Atlantic, Pacific and Indian oceans, and belong to three major genetic clades based on COI and $28 S$ DNA sequence data. Using a fossil-calibrated phylogeny, we estimated that these clades separated in the Late Oligocene and Early to Middle Miocene. We found evidence for ecological differentiation among all morphotypes based on ecological niche modelling with sea surface temperature, salinity and phytoplankton biomass as primary determinants. Across all analyses, we found highly congruent patterns of differentiation suggesting species level divergences between morphotypes. However, we also found distinct morphotypes (e.g. in the Atlantic Ocean) that were ecologically, but not genetically differentiated.

Conclusions: Given the distinct ecological and phenotypic specializations found among both described and undescribed Cuvierina taxa, they may not respond equally to future ocean changes and may not be equally sensitive to ocean acidification. Our findings support the view that ecological differentiation may be an important driving force in the speciation of zooplankton.

Keywords: Zooplankton, Integrative taxonomy, Geometric morphometrics, Molecular clock, Ecological niche modelling
\end{abstract}

\section{Background}

Shelled pteropods (Mollusca, Gastropoda: Thecosomata) are potentially good bioindicators of the effects of ocean acidification, but their application as such is hampered by limited knowledge of their taxonomy, genetic diversity, ecology and distribution patterns. Pteropods are a group of heterobranch gastropods [1] that are a common component of the marine zooplankton. They affect the ocean carbon cycle by producing aragonite shells that can accelerate the export of organic matter from

\footnotetext{
* Correspondence: Alice.Burridge@naturalis.nl

${ }^{1}$ Naturalis Biodiversity Center, P.O. Box 9517, Leiden 2300 RA, The Netherlands

${ }^{2}$ Institute for Biodiversity and Ecosystem Dynamics (IBED), University of Amsterdam, P.O. Box 94248, Amsterdam 1090 GE, The Netherlands Full list of author information is available at the end of the article
}

the surface into the deep ocean. Because of their delicate aragonite shells, pteropods have been identified as exceptionally vulnerable to rising $\mathrm{CO}_{2}$ (e.g. [2-4]), and hence are widely used to explore the effects of ocean acidification (e.g. [5-8]). Shelled pteropods also may be a particularly informative model system for the study of long-term marine evolutionary processes, because they are metazoan plankton with an abundant fossil record (e.g. $[9,10])$.

Recent studies suggest that marine plankton have higher evolutionary potential than originally thought and may be well poised for evolutionary responses to global change (e.g. [11-13]). A recent review of population genetic studies of oceanic zooplankton showed that genetic isolation can be achieved at the scale of gyre systems, and appears to be linked to the particular ecological requirements of 
the organisms [14]. Molecular phylogenetic studies on calcifying plankton have suggested greater specificity in oceanographic habitat preferences than previously supposed, e.g., in coccolithophores (e.g. [15,16]) and foraminifers (e.g. [16-22]). The evolutionary potential of calcifying plankton is further supported by long-term selection experiments, which have demonstrated rapid functional genetic divergence in response to elevated $\mathrm{CO}_{2}$ concentrations $[11,12]$. Hence, calcifying plankton may be capable of rapid evolutionary as well as ecological responses to changing ocean conditions, including future changes driven by global warming and ocean acidification.

The taxonomy of shelled pteropods has generally been based on shell morphology, although some studies have also examined soft parts (e.g. $[23,24])$. Several pteropod taxa have been identified using the traditional approach of univariate measurements of shell dimensions (e.g. [24-27]). Yet, the complex and highly diverse shell morphologies of pteropods also enable detailed geometric morphometric analyses. Several studies have shown that geometric morphometrics can be more powerful in distinguishing taxa than univariate measurements (e.g. [28-30]). Molecular phylogenetic studies suggested that taxonomic revisions will be required [31-33]. These studies showed a well-supported separation of species and genera, but relationships among genera are poorly resolved. The first genus-level study of pteropods focused on DNA barcoding of Diacavolinia, and emphasized the inadequacy of current systematic understanding of this genus [34]. The taxonomy of Creseis, Hyalocylis and Styliola was reviewed by [35].

This study focuses on the genus Cuvierina, an excellent model group for an integrative study of zooplankton because it has a worldwide distribution, it is abundantly present in museum collections, and has a well-described fossil record [25]. Moreover, the bottle-shaped adult shells $(6-11 \mathrm{~mm}$ in length) do not change during adult life, and can be easily distinguished from juvenile shells that are shed once the animal is mature [10,36]. Extant Cuvierina pteropods occur from $45^{\circ} \mathrm{N}$ to $40^{\circ} \mathrm{S}$, in ocean regions with surface water temperatures above $\sim 17^{\circ} \mathrm{C}$ [23]. Recent taxa are absent from the Mediterranean and Red Seas [25,37]. Cuvierina taxa have a diel vertical migration pattern and prefer epipelagic depths, with highest abundance between 100 and $250 \mathrm{~m}$ [37]. Cuvierina taxa are hermaphrodites and internal fertilizers [10]. The most recent taxonomic revision of Cuvierina was based on univariate shell measurements and a description of shell micro-ornamentation $[25,38]$. Based on fossil evidence [25] proposed that extant Cuvierina species evolved 5-4 million years ago (mya), with the origin of the first fossil species estimated at 25-24 mya. Janssen [25] proposed a subdivision of five extant morphospecies divided in two subgenera: Cuvierina (Urceolarica) cancapae [25], Cuvierina (Urceolarica) urceolaris [39], Cuvierina
(Cuvierina) columnella [40], Cuvierina (Cuvierina) atlantica [36], and Cuvierina (Cuvierina) pacifica [25]. However, recent studies of pteropods have not implemented this species-level revision, resulting in considerable taxonomic confusion [31-33,41]. Here, we follow and test the morphological taxonomy of [25], referring to the proposed Cuvierina taxa as morphotypes.

The overall aim of this study was to obtain a framework of phenotypic, genetic and geographic information to assess species boundaries and the evolutionary history of Cuvierina pteropods. To this end, we first applied geometric morphometric analyses of shell outlines using an extensive collection of museum and fresh specimens from the Pacific, Atlantic, and Indian Oceans. Secondly, we sequenced a portion of mitochondrial DNA (mtDNA) comprising a fragment of the cytochrome oxidase I (COI) subunit, as well as a portion of the nuclear 28S rDNA gene. Thirdly, we plotted global distribution patterns of Cuvierina morphotypes and applied ecological niche modelling to estimate their ecological tolerances. Our specific objectives were (1) to distinguish between and within extant taxa using an integrative approach (as suggested by e.g. [42]), (2) to determine the temporal sequence of evolution in the genus using a fossil-calibrated molecular phylogeny, and (3) to explore the current and past biogeographic context of extant Cuvierina taxa.

\section{Methods}

Samples

An overview of all Cuvierina samples is listed in Table 1 (more detailed information can be found in Additional file 1). Museum samples included specimens from the Natural History Museum of Denmark in Copenhagen (ZMUC) and Naturalis Biodiversity Center (NBC, Leiden, formerly Zoological Museum of Amsterdam (ZMA)). Museum samples were stored in $70 \%$ ethanol, but all museum samples had initially been fixed in formalin rendering them unsuitable for genetic analyses. Geographic locations of museum samples were either provided with the samples or obtained from [43-46] or [47]. Samples from ZMUC ( $\mathrm{N}=712$ from 80 locations, $1-46$ specimens per sample) were identified and sorted per morphospecies by A.W. Janssen (2001-2005 [25]) and served as reference museum samples for geometric morphometric analyses in this study (Figure 1, Table 1 and Additional file 1). Reference samples were collected during the Danish DANA expeditions between 1911 and 1934 during all seasons (53 locations), and during various other expeditions between 1846 and 1912 (27 locations) such as Leg. Andrea (Additional file 1: Table S1). Samples from NBC $(\mathrm{N}=214$ from 32 locations, 1-23 specimens per sample) were not identified according to the taxonomic revision of Cuvierina by [25] and are referred to as unidentified museum samples (Figure 1, Table 1). These samples were collected during 
Table 1 Overview of Cuvierina samples used in this study

\begin{tabular}{|c|c|c|c|c|c|}
\hline Morphotype & Ocean & $\begin{array}{l}\text { Morphometrics } \\
\text { ventral }\end{array}$ & $\begin{array}{l}\text { Morphometrics } \\
\text { apertural }\end{array}$ & $\mathrm{COI}$ & $28 \mathrm{~S}$ \\
\hline & Total & 1039 & 550 & 136 & 31 \\
\hline \multicolumn{2}{|c|}{$\begin{array}{l}\text { Reference museum } \\
\text { samples }\end{array}$} & 712 & 352 & & \\
\hline \multirow[t]{3}{*}{ C. atlantica } & & 226 & 83 & & \\
\hline & $\begin{array}{l}\text { North } \\
\text { Atlantic }\end{array}$ & 218 & 75 & & \\
\hline & $\begin{array}{l}\text { South } \\
\text { Atlantic }\end{array}$ & 8 & 8 & & \\
\hline \multirow[t]{2}{*}{ C. cancapae } & & 103 & 43 & & \\
\hline & $\begin{array}{l}\text { Central } \\
\text { Atlantic }\end{array}$ & 103 & 43 & & \\
\hline \multirow[t]{3}{*}{ C. columnella } & & 65 & 39 & & \\
\hline & Indian & 30 & 20 & & \\
\hline & Pacific & 35 & 19 & & \\
\hline \multirow[t]{3}{*}{ C. urceolaris } & & 226 & 95 & & \\
\hline & Indian & 137 & 49 & & \\
\hline & Pacific & 89 & 46 & & \\
\hline \multirow[t]{2}{*}{ C. pacifica $\mathrm{N}$} & & 34 & 34 & & \\
\hline & Pacific & 34 & 34 & & \\
\hline \multirow[t]{3}{*}{ C. pacifica S } & & 58 & 58 & & \\
\hline & $\begin{array}{l}\text { South } \\
\text { Pacific }\end{array}$ & 58 & 58 & & \\
\hline & & 58 & 58 & & \\
\hline \multicolumn{2}{|c|}{$\begin{array}{l}\text { Unidentified museum } \\
\text { samples }\end{array}$} & 214 & 83 & & \\
\hline & Atlantic & 168 & 37 & & \\
\hline & Pacific & 33 & 33 & & \\
\hline & Indian & 13 & 13 & & \\
\hline \multicolumn{2}{|c|}{$\begin{array}{l}\text { Unidentified fresh } \\
\text { samples }\end{array}$} & 113 & 115 & 133 & 31 \\
\hline & Atlantic & 60 & 61 & 72 & 14 \\
\hline & Pacific & 52 & 53 & 60 & 15 \\
\hline & Indian & 1 & 1 & 1 & 1 \\
\hline \multicolumn{2}{|c|}{ Genbank sequences* } & & & 3 & 1 \\
\hline & Atlantic & & & 1 & 1 \\
\hline & Indian & & & 2 & 0 \\
\hline
\end{tabular}

*GenBank sequences: COI, Atlantic: FJ876895, Indian: FJ876896-7 [32]; 28S, Atlantic: DQ237984 [33].

the DANA expeditions between 1911 and 1933 (21 locations), ACRE expeditions (1967-1968, 5 locations), and Project 101A (1980, 6 locations) (Additional file 1). Fresh samples $(\mathrm{N}=133$ from 53 locations, 1-23 specimens per sample) were collected between 2001 and 2012 during the following expeditions: MP3 (2001, 3 locations), 0106TRAN (2001, 1 location), COOK 11MV and 14MV (2001, 5 locations), DRFT07RR (2001, 3 locations), VANC10MV (2003,
1 location), MARECO (2004, 3 locations), ECO-CH-Z (2007, 9 locations, provided by R.A. Gasca Serrano, Unidad Chetumal, Mexico), AMT18 (2008, 3 locations), R/V Tansei-Maru KT-10-20 (2010, 1 location, provided by H. Miyamoto, University of Tokyo, Japan), Kilo Moana 1109 (2011, 4 locations), AMT22 (2012, 14 locations), and KH11-10 (2011-2012, 6 locations, provided by A. Tsuda, University of Tokyo, Japan) (Figure 1, Additional file 1). The collection nets used had mesh sizes between 0.2 and $1 \mathrm{~cm}$. Fresh samples were stored in $96 \%$ ethanol. Only mature individuals with intact shells, both museum and fresh specimens, were used for geometric morphometric analyses. All fresh individuals were used for genetic analyses $(\mathrm{N}=133)$ (Table 1 and Additional file 1).

\section{Geometric morphometrics}

Specimens were photographed in two orientations: ventral and apertural (Figure 2). Photographs were taken with a Nikon D100 6 mpx camera (Micro-Nikkor lens $55 \mathrm{~mm} / 3.5$, aperture $\mathrm{f} / 16$, shutter speed $1 / 8 \mathrm{~s}$ ISO 200, fixed zoom), which was attached to a stand. For ventral photography, specimens were mounted on photographic film with methyl glucose $(60 \%)$ to standardize the orientation. For apertural photography, shells were put into small disposable pipette tips. Photographs were adjusted in Adobe Photoshop Lightroom 2-2008 on white balance, sharpness, vibrancy and noise. Files containing pictures selected for analysis were prepared using tpsUtil [48]. Only well-focused, undamaged adult shells in standardized orientation were used.

Because there are no true landmarks on Cuvierina shells, we used semi-landmarks for outlining shells [49]. Ventral shell outlines were created in tpsDig [48] for a total of 1039 specimens, and apertural outlines were applied to a subset of 550 specimens (Figure 2, Table 1). The ventral outline was created by starting and ending at the distinct transitions from the outside of the shell to the aperture. One separate semi-landmark was placed at the top of the aperture. Using tpsUtil [48] the outline was converted to 75 semi-landmarks, separated by equal length, enabling further analyses (Figure 2). The apertural outline started with the semi-landmark in the middle of the aperture edge (the upper semi-landmark shown for typical specimens in Figure 2), being one of 35 semi-landmarks in which the apertural outline was converted. TpsRelw [48] was used to rotate, translate and scale semi-landmark coordinates through generalized least square Procrustes superimposition (GLS) ([50], in [51]). GLS provided centroid sizes (a size measure depending on surface area) and multiple relative warp axes (RWs; ventral $\mathrm{N}=148$; apertural $\mathrm{N}=70$ ) per specimen. RWs contain information on shape, with the first RW containing the most shape information. To test for repeatability of RWs, a selection of 44 specimens 


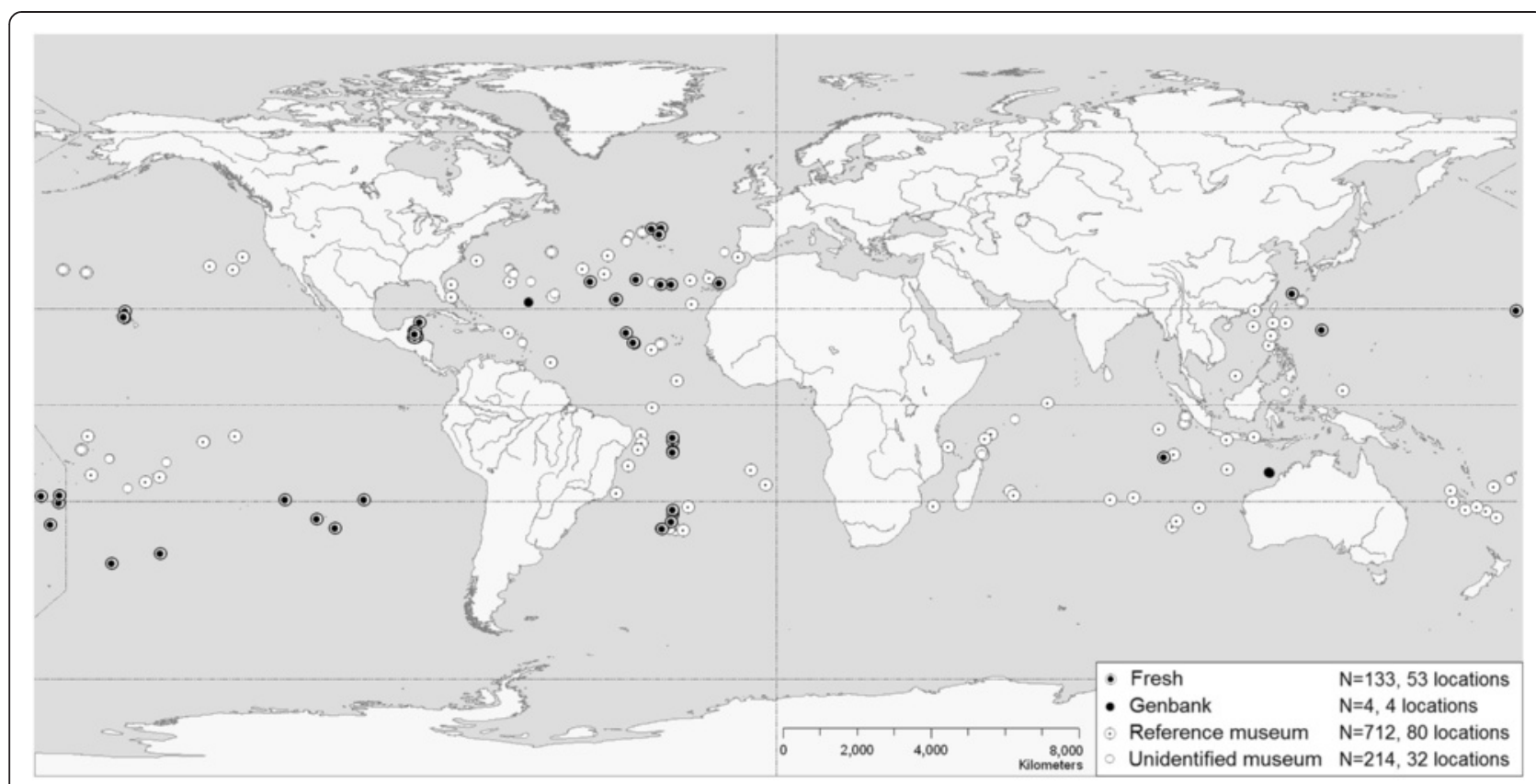

Figure 1 Geographic overview of all Cuvierina specimens used in this study. Some sampling locations of reference and unidentified museum samples overlap.

was photographed in two subsequent series. Intraclass correlation coefficients (ICCs) between the two series were calculated for the first $10 \mathrm{RWs}$ in Past 3.0 [52]. RWs were considered repeatable when ICC $>0.80$. The outline method for geometric morphometric analyses on Cuvierina shells was highly repeatable (ICC $>0.89$ for ventral RWs $1,2,4,5,6$ and centroid size; ICC $>0.82$ for apertural RWs 1, 2, 4, 5 and centroid size). Only repeatable RWs were used in further analyses of shell shape. To test whether sliding semi-landmarks provided more consistent results, ICCs were also calculated after transformation of semi-landmarks separated by equal-length intervals into sliding semi-landmarks with estimated positions on the outline. This did not improve repeatability; hence only semi-landmarks were used in this study.

The $a$ priori classification of reference museum specimens (those identified by [25]), was compared to results of clustering by linear discriminant analyses (LDA) in R 3.0.1 [53]. Parameters for identifying morphotypes using LDA were ventral centroid size and ventral RWs 1, 2, 4, 5, 6. Subsequently, we compared our manual morphotype identifications of previously unidentified museum and fresh specimens to results of LDA-assignment of these specimens to morphotypes. Our manual identification of unidentified specimens was based on ventral centroid size, ventral RWs 1, 2, 4, 5, 6, and if available, apertural centroid size and apertural RWs 1, 2, 4, 5. The performance of the LDA algorithm was tested by cross-validation using a jackknifed confusion matrix in Past 2.17c [52].
To test for significant differentiation between a priori defined groups of Cuvierina (morphotypes or geographic distributions), we applied non-parametric permutational multivariate analyses of variance (PerMANOVA, [54]) in Past 2.17c. We used Euclidean distances applied to ventral and apertural centroid sizes and RWs with ICC > 0.80 (representing $96.75 \%$ of shell shape variation). The PerMANOVA $F$-statistic was tested against 9999 nonparametric permutations.

\section{Genetics}

To assess levels of genetic variation within Cuvierina, we sequenced 133 individuals for COI mtDNA and 31 individuals for $28 \mathrm{~S}$ rDNA (Table 1). Entire juveniles $(\mathrm{N}=4)$ and $2 \times 2 \mathrm{~mm}$ of tissue of adults $(\mathrm{N}=129)$ were individually placed in BLB buffer (250 mM EDTA, 5\% SDS, $50 \mathrm{mM}$ Tris- $\mathrm{HCl} \mathrm{pH} 8.0$; [55]) for at least $24 \mathrm{~h}$. Total DNA was extracted from BLB buffer using the DNeasy blood \& tissue kit (Qiagen Benelux B.V. 2006). The extract was resuspended in $100 \mu \mathrm{l} \mathrm{AE-buffer} \mathrm{(Qiagen} \mathrm{Benelux}$ B.V.). A $658 \mathrm{bp}$ fragment of COI was amplified using the primers LCO1490 (5'-GGTCAACAAATCATAAAGAT ATTGG-3') and HCO2198 (5' ${ }^{\prime}$-TAAACTTCAGGGTG ACCAAAAAATCA-3') [56]. For a subset of 31 individuals, a 965 bp $28 \mathrm{~S}$ rDNA fragment was amplified using the primers 28SC1F (5'-ACCCGCTGAATTTAAGCA T-3') and 28SD3R (5'-GACGATCGATTTGCACGTC A-3') [57]. Most polymerase chain reactions (PCR) of COI and 28S, with total volumes of $25 \mu \mathrm{l}$, contained PCR 


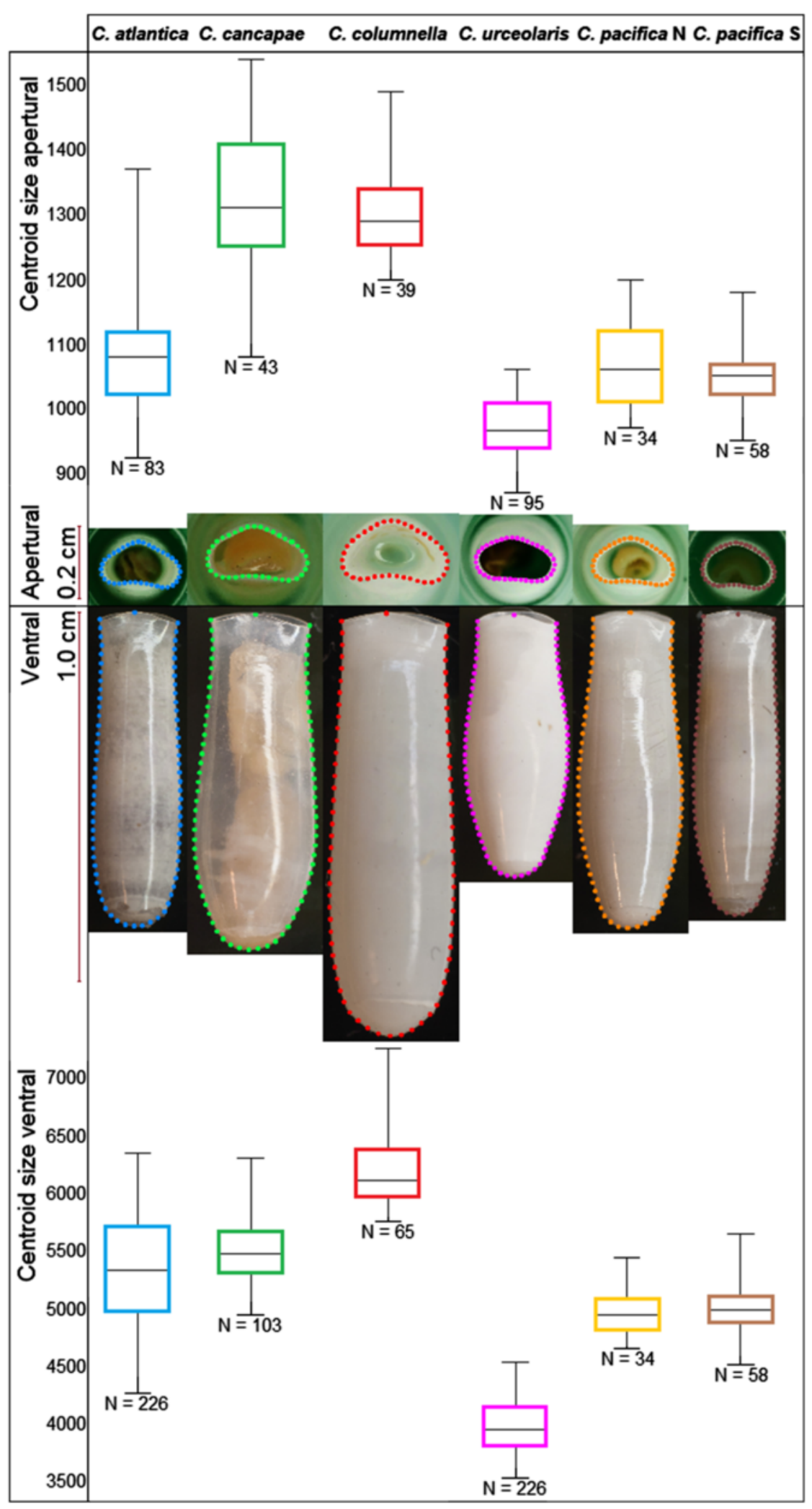

Figure 2 Centroid size variation for reference museum specimens of Cuvierina in ventral $(\mathrm{N}=712)$ and apertural $(\mathrm{N}=352)$ orientations. Typical specimens of six morphotypes are shown with outlines transformed to semi-landmarks to allow for geometric morphometric analysis. Lengths of Cuvierina shells were between 0.6 and $1.1 \mathrm{~cm}$. 
Beads (GE Healthcare Europe $\mathrm{GmbH}$ ) with $3 \mu$ lemplate

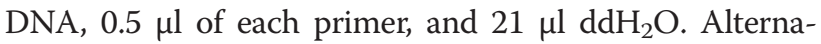
tively for COI, PCR solutions $(25 \mu \mathrm{l})$ contained $3 \mu \mathrm{l}$ template DNA, $2.5 \mu \mathrm{l}$ 10x reaction buffer (HT Biotechnology, Cambridge, U.K.), $1 \mu \mathrm{l} \mathrm{MgCl}$ (25 mM), $2.5 \mu \mathrm{l}$ dNTPs (GATC $1 \mathrm{mM}$ each), $0.3 \mu \mathrm{l}$ of each primer $(10 \mu \mathrm{M})$, $0.15 \mu \mathrm{l}$ Taq polymerase (HT Biotechnology), $0.2 \mu \mathrm{l}$ BSA $(10 \mathrm{mg} / \mathrm{ml})$ and $15.05 \mu \mathrm{lddH_{2 }} \mathrm{O}$. Amplifications were carried out in a PTC-200 DNA Engine Cycler (Bio-Rad Laboratories B.V.) with an initial denaturation of $3 \mathrm{~min}$ at $94^{\circ} \mathrm{C}, 35$ cycles of $45 \mathrm{~s}$ at $94^{\circ} \mathrm{C}, 1 \mathrm{~min}$ at $45^{\circ} \mathrm{C}$, and $1.5 \mathrm{~min}$ at $72^{\circ} \mathrm{C}$, followed by final extensions of $10 \mathrm{~min}$ at $72^{\circ} \mathrm{C}$ and $5 \mathrm{~min}$ at $4^{\circ} \mathrm{C}$. Sequencing of PCR products was carried out using both PCR primers by Macrogen Europe. The genus-level identities of all sequences were confirmed by BLAST searching GenBank [58]. Sequences were aligned in CodonCode Aligner 4.1 (CodonCode Corporation, USA, 2013). Additional GenBank sequences were added, namely three for COI ('C. columnella'): FJ8768957 [32] and one for 28S ('C. columnella'): DQ237984 [33].

To estimate evolutionary relationships among COI haplotypes, we applied a Maximum Likelihood (ML) approach [59] in raxmlGUI 1.3, which only provides GTRrelated models of rate heterogeneity for nucleotide data $[60,61]$. We tested for the most appropriate model of sequence evolution for this dataset using AIC in jModelTest 2.1.3 [62] based on 88 models and the GTR $+\Gamma+\mathrm{I}$ was selected. However, we use 3 codon positions (CP) instead of $\Gamma+\mathrm{I}$ because it is a biologically realistic model for protein coding sequences (following [63]). We applied a ML search followed by a non-parametric bootstrap analysis with 2000 replicates. Additionally, we calculated pairwise genetic distances for COI in MEGA 6.0 using the p-distance model of evolution [64].

To test for congruence of mitochondrial clades with nuclear DNA, we reconstructed alleles from $28 \mathrm{~S}$ genotypes using the PHASE algorithm [65,66] in DnaSP v5 [67] and used these to calculate pairwise genetic distances with the p-distance model of evolution in MEGA 6.0.

We further explored the population genetic structure of Cuvierina in the Atlantic Ocean based on the COI fragment using a total of 60 fresh specimens for which morphotypes were assigned (northern C. atlantica $(\mathrm{N}=34$ ), southern C. atlantica $(\mathrm{N}=21)$ and central Atlantic C. cancapae $(\mathrm{N}=5)$; Additional file 1). The number of fresh specimens from the Indian and Pacific Oceans was insufficient for population genetic analyses. We obtained haplotype diversity $(\mathrm{H})$ and nucleotide diversity $(\pi,[68,69])$ for each population sample and pooled samples per morphotype and/or geographic region using Arlequin 3.5.1.3 [70]. We tested for differentiation between Atlantic morphotypes and between geographic regions within morphotypes (e.g. North Atlantic versus South Atlantic) using $\phi_{\mathrm{ST}}$ based on pairwise differences. These were tested for divergence from the null distribution of no differentiation with 10000 permutations, as implemented in Arlequin. For all analyses involving multiple simultaneous tests, significance levels were adjusted by application of a sequential Bonferroni correction with an initial alpha of 0.05 [71].

To reconstruct evolution within Cuvierina and to provide a phylogenetic perspective of outgroup relationships, 30 Cuvierina sequences were compared to other Cavoliniid taxa. This approach was applied to combined partitions of COI (658 bp) and $28 \mathrm{~S}$ (989 bp). Outgroup taxa were Creseis conica, Clio pyramidata, C. cuspidata, C. recurva, Diacria danae and D. trispinosa. The AIC in jModelTest 2.1.3 based on 88 models suggested the use of GTR $+\Gamma+$ I for COI and GTR $+\Gamma$ for 28 S. Firstly, we applied a ML search followed by non-parametric bootstrap analysis with 3500 replicates in raxmlGUI 1.3. For this purpose, we used the GTR + CP substitution model for COI following [63]. Secondly, we applied a relaxed Bayesian molecular clock analysis to combined COI and $28 \mathrm{~S}$ partitions with uncorrelated lognormal rates in BEAUti and BEAST 1.7.5 [72]. For this we used the models suggested by jModelTest 2.13, because CP-based reconstructions failed to reach an Effective sample size (ESS) $>100$ for the posterior statistic after two runs of $10^{9}$ generations (burn-in $2 \times 10^{8}$ generations), as visualized in Tracer 1.5 [73]. The tree prior was set to the Yule Process of speciation [74] with a random starting tree. Because our dataset consists of intraspecific as well as interspecific sequences, we limited our dataset to one individual per taxon, but used two individuals of $C$. pacifica $\mathrm{S}$ to calculate the TMRCA of this clade. We included the most basally positioned individuals for each morphotype based on the ML-phylogeny of COI and $28 \mathrm{~S}$ combined. Two fossil calibrations were used, one on the root node of the tree (= stem Cavolinoidea) and one for the time of most recent common ancestry (TMRCA) of extant Cuvierina. For the first calibration we used the first fossil occurrence of the now extinct Cavoliniid Camptoceratops priscus [75], 47.8-56 mya (Ypresian stage, A.W. Janssen, pers. comm. and in accordance with [31]) and set a lognormal distributed prior $(\log ($ Mean $)=8.0 ; \log ($ Stdev $)=$ 0.7; offset $=48.0$ ). For the crown node of Cuvierina we set a lognormal distributed prior $(\log ($ Mean $)=3.0 ; \log ($ Stdev $)=$ 0.5 ; offset $=23.0$ ) based on the first occurrence of Cuvierina torpedo in the fossil record at 20.4-23 mya [25,76]. The preliminary MCMC chain was $10^{7}$ generations (burnin $10^{6}$ generations), followed by six runs of $2.5 \times 10^{8}$ generations (burn-in $2.5 \times 10^{6}$ generations each). We sampled trees and log-likelihood values at 10 000generation intervals. Sets of trees obtained during independent runs were combined in LogCombiner 1.7.5 [72] and the maximum clade credibility tree was selected using TreeAnnotator 1.7.5 [72]. 


\section{Ecological niche modelling}

To test whether Cuvierina morphotypes were ecologically differentiated based on their biogeographic distributions, we applied ecological niche modelling (ENM) to estimate their ecological tolerances. Based on geometric morphometric analyses, we plotted global morphotype occurrences on maps containing marine environmental data from the Bio-ORACLE dataset [77] in a WGS1984 coordinate system in ArcMap 10.0 (ESRI LTD., USA, 2011) to obtain an indication of geographic distributions in relation to the ecological variables. The number of georeferenced sampling locations for each morphotype was 69 for $C$. atlantica, 14 for C. cancapae, 17 for C. columnella, 30 for C. urceolaris, 20 for C. pacifica $\mathrm{N}$, and 20 for C. pacifica S, respectively. We calculated Spearman rank correlation coefficients $(\rho)$ between the environmental variables and performed a principal component analysis (PCA) on all Bio-ORACLE data layers. The PCA was used to select the most informative ecological variables from sets of correlated variables. This reduced the effect of collinearity of environmental variables [78]. Six uncorrelated data layers (with $\rho$ ranging from- 0.48 to 0.72 ), all with a spatial resolution of 5 arcmin $(c a .9 .2 \mathrm{~km}$ ), were selected for ENM: maximum monthly sea surface temperature (SST), annual SST range, annual average sea surface salinity (SSS), annual average surface $\mathrm{pH}$, maximum monthly photosynthetically active radiation reaching the ocean surface (PAR) and maximum monthly near-surface chlorophyll $a$ concentration. The Bio-ORACLE layers SST, chlorophyll $a$ and PAR were based on remotely sensed data [77]. Maximum monthly chlorophyll $a$ concentration was set to a maximum of $10 \mathrm{mg} / \mathrm{m}^{3}$ and annual average SSS was set to a minimum of $30 \mathrm{PSU}$ as seen in nature. Although Cuvierina taxa are most abundant between 100 and $250 \mathrm{~m}$, they migrate daily between surface waters and greater depths [37]. It is therefore likely that sea surface variables are an important dimension of Cuvierina's niche. Using MaxEnt 3.3.3 k [22,79] we created response curves for these six ecological variables, performed jackknife tests to measure the importance of individual environmental variables in explaining the modelled distribution of each morphotype, and estimated potential niches per morphotype. Response curves were not extrapolated outside the range of observed values. We used the default settings and all presence records $(\mathrm{N}=170)$ for training our model. Accuracy of ENMs per morphotype was examined using a nullmodel methodology using 99 randomisations that allows for significance testing of ENMs [80]. This test corrects for collection bias by restricting the randomly drawn points to all known sampling locations (presence-only data). Niche overlap between pairs of morphotypes was calculated by the Schoener's $D$ statistic $[81,82]$ in ENMTools [83]. A $D$ value of 1 indicates that two species share the same environmental space and a $D$-value of 0 suggests no overlap.

\section{Results}

\section{Phenotypic variation}

We distinguished six morphotypes in the pteropod genus Cuvierina based on geometric morphometric analyses of shell shape and size of reference specimens (Figures 2 and $3)$. Because we found a separation between the North and South C. pacifica morphotypes (Figures 2, 3 and Additional file 2, respectively), these were separated in further analyses and are referred to as C. pacifica $\mathrm{N}$ and C. pacifica S. All morphotypes were significantly different from each other in terms of centroid size (ventral $F=731.7 ; p<0.001$ ) except C. pacifica $\mathrm{N}$ and C. pacifica $\mathrm{S}$ (Figure 2). Separation in size and shape was most evident in ventral orientation. Here, the overall shell shape variation between six morphotypes was significant after strict Bonferroni correction $(\mathrm{N}=712$, $96.89 \%$ of shape variation; $F=1364 ; p<0.001)$. Extremes on the first RW axis (explaining $91.53 \%$ of ventral shell shape variation) were represented by the cylindrical C. atlantica and the bottle-shaped C. urceolaris, respectively (Figure 3). Extremes on the second RW axis (explaining 3.61\% of ventral shell shape variation) were $C$. pacifica $\mathrm{S}$ with a narrow shell bottom (septum) and C. cancapae with a broad septum, respectively. In an apertural orientation, two of the six morphotypes (C. urceolaris and C. pacifica S) were significantly differentiated $(\mathrm{N}=352 ; 84.59 \%$ of shape variation; $F=232.1 ; p<0.001)$.

We also found significant variation in shell shape and size within morphotypes for C. columnella and C. urceolaris from different geographic regions. C. columnella specimens from the Indian Ocean $(\mathrm{N}=30)$ were significantly larger than Pacific specimens $(\mathrm{N}=35 ; F=25.44 ; p<0.001)$. The opposite was true for $C$. urceolaris: specimens from the Indian Ocean $(\mathrm{N}=137)$ were significantly smaller than Pacific specimens $(\mathrm{N}=89 ; F=123.7 ; p<0.001)$. We found no significant shape and size differences between $C$. atlantica specimens from the northern $(\mathrm{N}=255)$ and southern $(\mathrm{N}=28)$ Atlantic populations.

Linear Discriminant Analyses (LDA) almost completely matched manual morphotype identifications based on geometric morphometric analyses of unidentified specimens and showed high correspondence with a priori classification of reference museum samples. Without assigning samples to ocean basins a priori, 96\% of all reference specimens $(\mathrm{N}=712)$ were assigned to the same morphotype as determined a priori. Confidence increased to $99 \%$ when samples from the Atlantic and Indo-Pacific were analysed separately. We compared this assignment method to LDA and found that without separating samples from the Atlantic and Indo-Pacific basins, $91 \%$ of all fresh specimens $(\mathrm{N}=113)$ and $96 \%$ of all unidentified museum specimens $(\mathrm{N}=214)$ were assigned to the same morphotypes as in manual identifications. This accuracy increased when samples were distinguished geographically: $96 \%$ of all fresh specimens and $99.5 \%$ of unidentified 


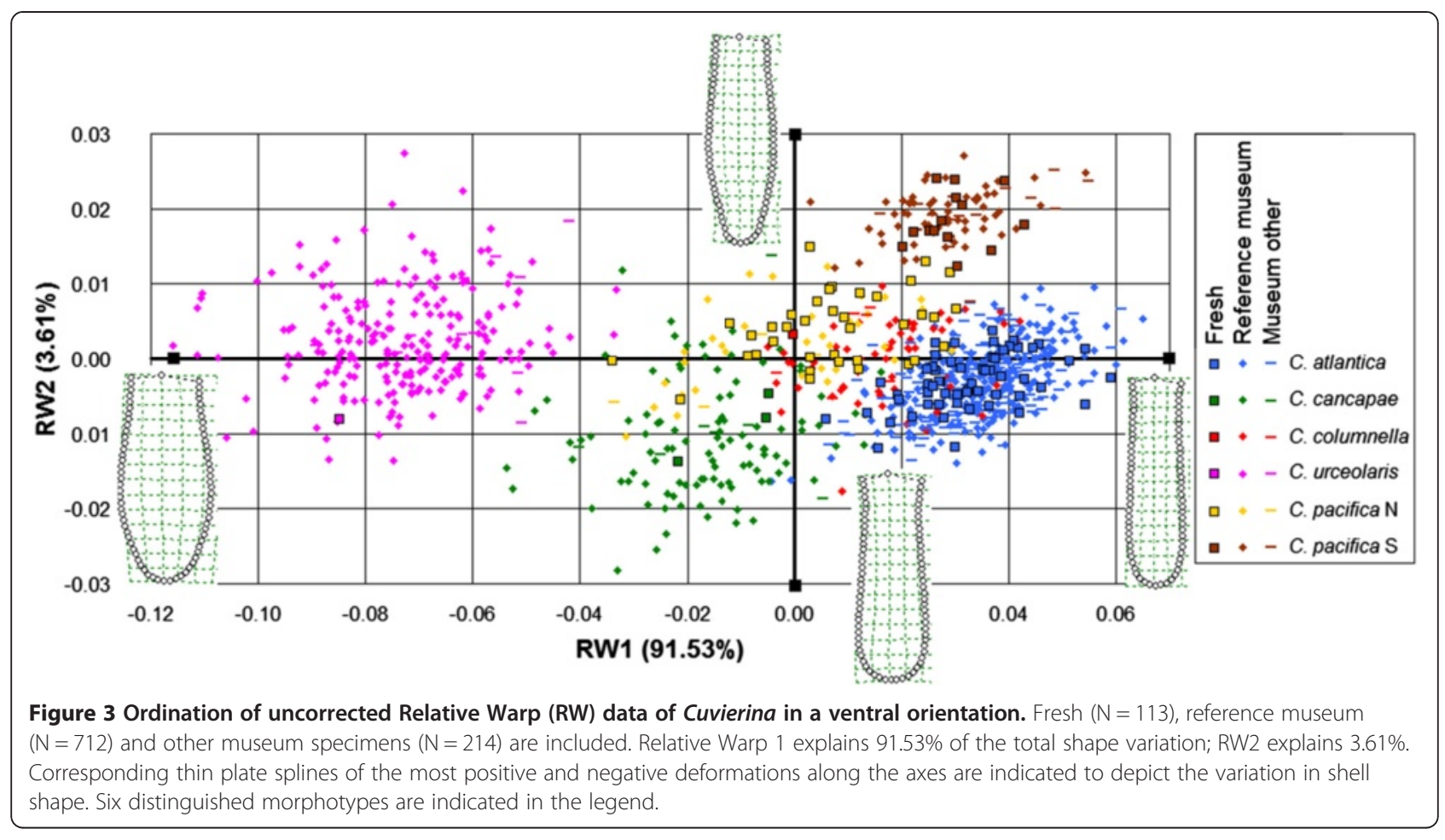

museum specimens were assigned to the same morphotype as with our manual method. We chose our manual method as the final identification method because a few specimens could not be identified unambiguously by LDA. These specimens had either shapes or centroid sizes that were on the edges of the total size-range or morphospace of a specific morphotype. Cross-validation demonstrated a high accuracy of the LDA algorithm itself: $98 \%$ of Atlantic and $99.5 \%$ of Indo-Pacific reference museum samples were identified as true positives.

\section{Genetic variation}

We found high levels of mitochondrial diversity in a data set of 136 COI sequences collected from global samples of Cuvierina, including 127 different haplotypes represented by 166 polymorphic sites (GenBank accession numbers KP292656-KP292788; Additional file 1). We translated COI sequences into amino acids and discarded the possibility of pseudogenes because we found no stop codons and no insertions or deletions. Phylogenetic analysis of COI sequences indicated the presence of three major mitochondrial clades (Figure 4 and Additional file 3). These three monophyletic clades were highly supported (bootstrap values of 84-99\%) are largely congruent with morphotypes as well as geographic distributions (Figure 5). The three major clades were named after their geographic distributions; viz., Atlantic, Indo-Pacific and South Pacific (Figures 4 and 5). The Atlantic clade contains both the $C$. atlantica and $C$. cancapae morphotypes: we did not find any grouping of these morphotypes, nor did we find any grouping of individuals from either the North or South Atlantic. The Indo-Pacific clade consists of C. urceolaris, C. pacifica $\mathrm{N}$ and C. columnella morphotypes. Within this clade, $C$. pacifica $\mathrm{N}$ was paraphyletic. Our single specimen of the $C$. urceolaris morphotype grouped with two GenBank sequences from the Indian Ocean (both reported as C. columnella, [32]). The South Pacific clade consists entirely of the $C$. pacifica $\mathrm{S}$ morphotype. Average pairwise genetic distances of COI were $4.5-5.1 \%$ between major

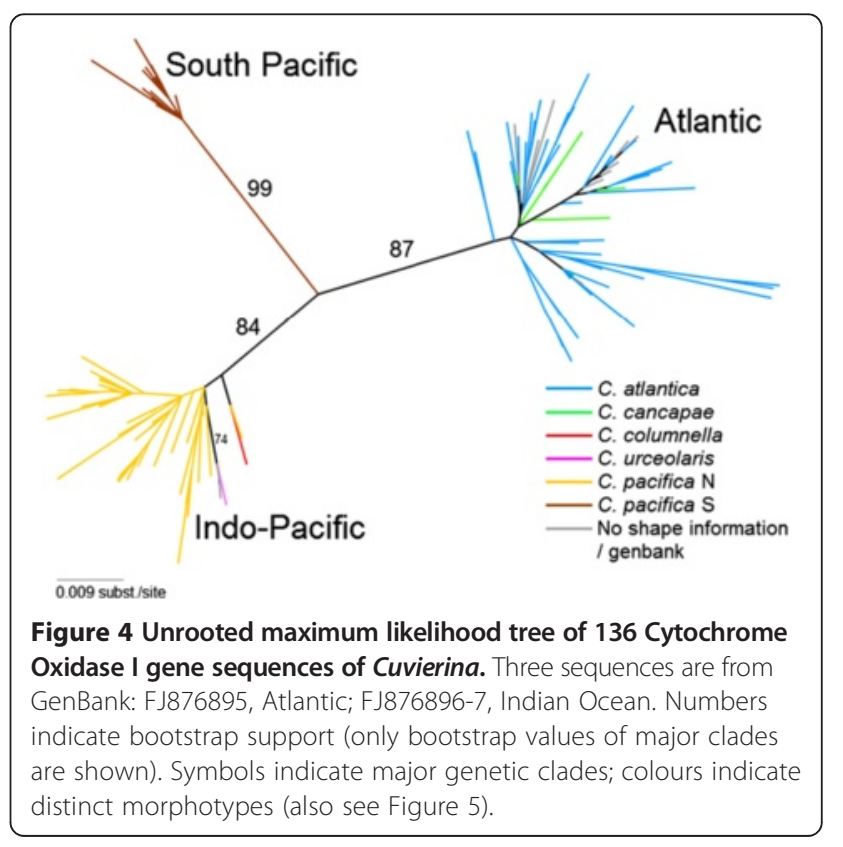




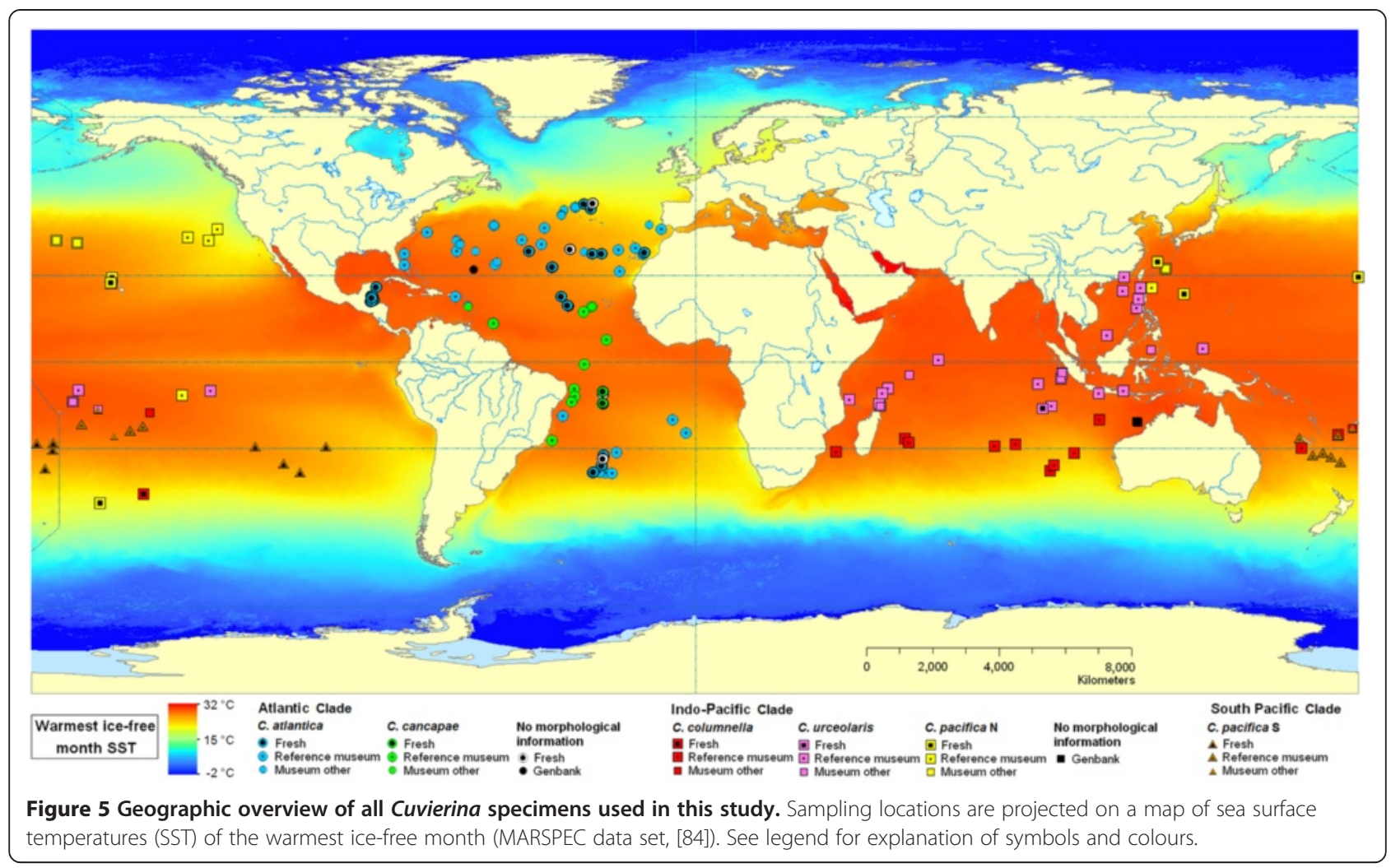

clades and $2.0 \%, 1.7 \%$ and $0.8 \%$ within clades for the Atlantic, Indo-Pacific and South Pacific, respectively (Additional file 4).

Genetic patterns in $28 \mathrm{~S}$ were not in conflict with our COI data but contained much less variation $(0.8 \%$ for $\mathrm{N}=31$ representing 6 morphotypes). We found 11 diploid genotypes represented by 13 phased alleles and a total of 8 polymorphic sites (GenBank accession numbers KP292620-KP292649; Additional files 1 and 4). Most Cuvierina morphotypes shared 28S sequences, however, C. pacifica $\mathrm{S}$ and our single C. urceolaris specimen had unique single substitutions at positions 866 and 678, respectively (both $\mathrm{C}$ instead of $\mathrm{T}$ ). Average pairwise genetic distances of $28 \mathrm{~S}$ were $0.03 \%, 0.1 \%$ and $0.09 \%$ within the Atlantic, Indo-Pacific and South Pacific mitochondrial clades, and $0.14-0.26 \%$ between major clades (Additional file 4).

Because we found $C$. atlantica populations in the northern as well as southern Atlantic Ocean, which are separated geographically by C. cancapae (Figure 5), we tested for spatial genetic structuring. Overall, we found high levels of genetic diversity in Atlantic Cuvierina samples (haplotype diversities ranged from 0.99 to 1.0 per sample). Nucleotide diversities were comparable for northern C. atlantica $(\pi=0.020 \pm 0.01, \mathrm{~N}=34)$, southern C. atlantica $(\pi=0.022 \pm 0.01, \mathrm{~N}=21)$ and $C$. cancapae $(\pi=0.020 \pm 0.01, N=5)$. We found significant population genetic structuring of northern versus southern $C$. atlantica populations ( $\phi_{\mathrm{ST}}=0.047, p=0.008$ ), but not between C. cancapae and any C. atlantica population. This could be due to low sample size of C. cancapae.

We reconstructed evolution within the genus Cuvierina based on ML and fossil-calibrated Bayesian phylogenetic analyses of the combined $\mathrm{COI}+28 \mathrm{~S}$ sequence data (Additional file 3 and Figure 6, respectively). The ML and Bayesian reconstructions established a wellsupported monophyly of Cuvierina versus outgroup taxa (GenBank accession numbers KP292650-KP292655 and KP292789-KP292794; Additional file 1). Within Cuvierina, the South Pacific clade appears basal in both reconstructions, followed by a split between the Atlantic and Indo-Pacific. We found that evolutionary rates of COI and $28 \mathrm{~S}$ in outgroup taxa were highly variable and outgroup relationships remained largely unresolved $(\mathrm{PP}<0.50$; ML bootstraps $<40$ ). Creseis, the sister taxon of Cuvierina based on interpretation of fossil evidence by [25], had the fastest evolutionary rate with respect to the other taxa based on our Bayesian analyses (Figure 6). Following the TMRCA of 25.3 (28-23, 95\% confidence intervals) mya (Oligocene) for the genus Cuvierina, the first divergence most likely took place between the South Pacific and the Indo-Pacific/Atlantic clades. The Indo-Pacific and Atlantic clades diverged 16.1 (24.5-7) mya (Miocene). The TMRCA for recent taxa within these three major clades 


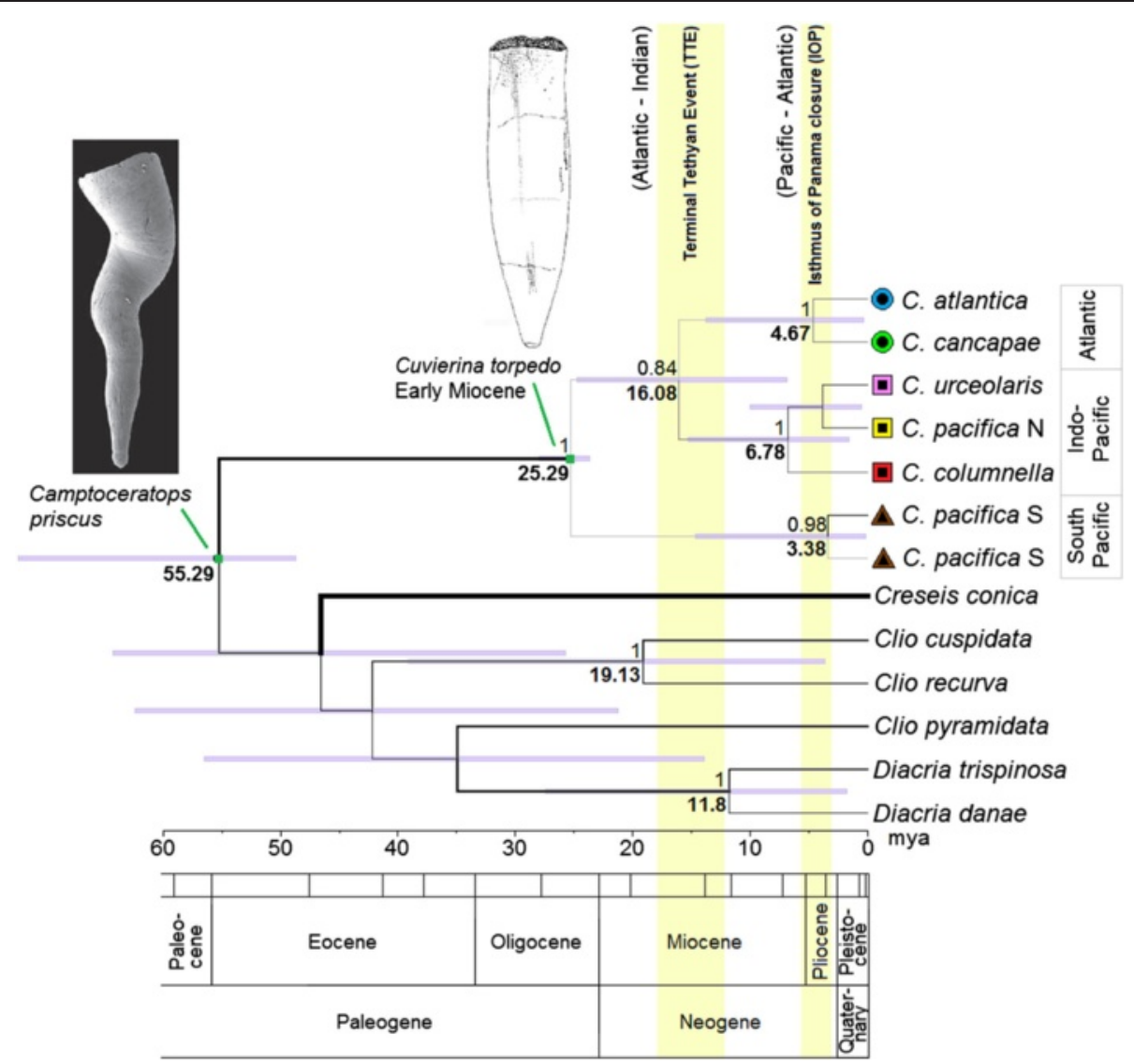

Figure 6 Fossil calibrated Bayesian phylogeny of 7 Cuvierina and 6 outgroup taxa using COI (658 bp) and $28 \mathrm{~S}$ (989 bp). The reconstruction was calibrated by the earliest occurrences in the fossil record of Camptoceratops priscus and Cuvierina torpedo, indicated by green dots on the nodes. Numbers above major branches indicate posterior probabilities (only values $>0.95$ are shown); numbers below major branches indicate ages in million years ago. Branch widths correspond to substitution rates, with thick branches indicating high substitution rates. Symbols for Cuvierina indicate major genetic clades; colours indicate morphotypes (also see Figure 5). Image of C. priscus: [85]; and C. torpedo: [76]. The TTE and IOP are highlighted after estimations by [86].

was estimated at least 4.7 (13.5-1) mya for the Atlantic, 6.8 (15-2) mya for the Indo-Pacific, and 3.4 (14.5-0.5) mya for the South Pacific clades.

\section{Biogeography}

Cuvierina morphotypes are restricted to warm tropical and subtropical oceanic waters between ca. $43^{\circ}$ north and ca. $40^{\circ}$ south (Figure 5). We found little range overlap between Cuvierina morphotypes, especially in the Atlantic and Indian Oceans. However, Pacific distributions of morphotypes of the Indo-Pacific clade (C. columnella, C. pacifica $\mathrm{N}$ and C. urceolaris) partly overlapped (Figure 5). In the Atlantic Ocean, the C. cancapae morphotype is found in equatorial waters, extending as far as $23^{\circ}$ south, whereas $C$. atlantica appears in subtropical waters up to $43^{\circ}$ north and $35^{\circ}$ south. In the Indian Ocean, C. urceolaris is found in equatorial waters, whereas $C$. columnella appears in subtropical waters up to $35^{\circ}$ south. In the Pacific Ocean, $C$. urceolaris is found in equatorial waters, but $C$. columnella appears in equatorial as well as southern waters up to $40^{\circ}$ south. The $C$. pacifica $\mathrm{N}$ morphotype has a much wider distribution pattern. It is confined to the Pacific Ocean and has been observed in northern subtropical waters up to $38^{\circ}$ north, but also at a few equatorial and southern sampling sites. The C. pacifica $\mathrm{S}$ morphotype is confined to the large South Pacific gyre (Figure 5).

Based on response curves, MaxEnt jackknife scores and Schoener's $D$ values, we found evidence for ecological differentiation among all six morphotypes (Figure 7, Table 2, Additional file 5). The relative contributions of individual oceanographic variables in explaining distribution patterns differed across morphotypes (Table 2). In the Atlantic Ocean, maximum monthly SST was most important in explaining the range of $C$. cancapae (41.9\% contribution), indicative of its preference for warm waters (Figure 7). Other range-explaining variables were annual SST range (22.8\%) and annual average SSS (34.6\%). The distributional range of $C$. atlantica, however, was predominantly explained by annual average SSS (73.9\%), and to a much 

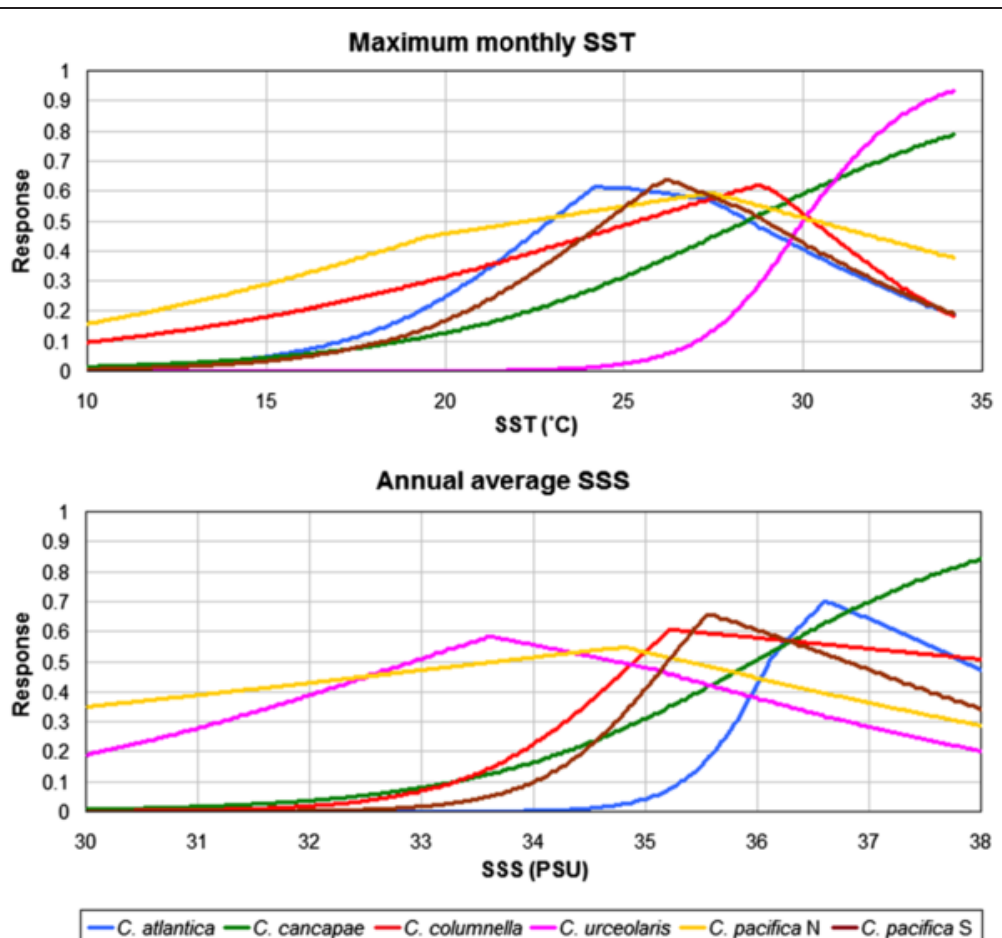

Figure 7 Ecological niche modelling response curves for each Cuvierina morphotype. Only response curves for maximum monthly Sea Surface Temperature (SST) and annual average Sea Surface Salinity (SSS) are shown.

smaller extent by maximum monthly SST (7.7\%). The Indo-Pacific ranges of $C$. urceolaris were to a great extent explained by maximum monthly SST (86.3\%), indicating a preference for warm waters (Figure 7), whereas maximum monthly PAR reaching the ocean surface (high) and chlorophyll $a$ concentration (low) were important to the distribution of C. columnella. No single oceanographic variable was found to predominantly explain the broad range of $C$. pacifica $\mathrm{N}$, but maximum monthly SST and near-surface chlorophyll $a$ concentration (both 30.8\%) and SSS (21.5\%) contributed most. The distribution of C. pacifica $\mathrm{S}$ was predominantly defined by maximum monthly chlorophyll $a$ concentration (57.1\%; Table 2), indicative of a preference for waters with low surface phytoplankton biomass. All six ENMs per morphotype were accurate according to significance testing using presence-only data (AUC-values 0.884-0.9588; lowest $p=<0.03$ ).

\section{Discussion}

\section{Species boundaries}

By conducting a global study combining phenotypic, genetic and biogeographic analyses of a zooplankton taxon, we show that the approach of integrative taxonomy can greatly improve our understanding of biodiversity and evolution in the open ocean. We have revealed congruent morphological, genetic and ecological patterns in Cuvierina, which all proved to be informative for distinguishing between taxa. We found evidence for six distinct morphotypes

Table 2 MaxEnt Jackknife scores representing the relative importance of environmental variables in explaining distribution patterns of Cuvierina morphotypes

\begin{tabular}{|c|c|c|c|c|c|c|}
\hline$\%$ Contribution & C. atlantica & C. cancapae & C. columnella & C. urceolaris & C. pacifica $\mathrm{N}$ & C. pacifica S \\
\hline SST max. & 7.7 & 41.9 & 9.1 & 86.3 & 30.8 & 12.5 \\
\hline Chlorophyll a max. & 3.9 & 0.7 & 53.4 & 3.3 & 30.8 & 57.1 \\
\hline SSS average & 73.9 & 34.6 & 1.6 & 5.9 & 21.5 & 7.0 \\
\hline PAR max. & 4.1 & 0.0 & 31.5 & 0.0 & 12.3 & 7.5 \\
\hline SST range & 9.3 & 22.8 & 2.6 & 0.7 & 4.6 & 2.0 \\
\hline $\mathrm{pH}$ average & 1.1 & 0.0 & 1.8 & 3.8 & 0.0 & 13.9 \\
\hline
\end{tabular}

SST max. = maximum monthly sea surface temperature (SST), Chlorophyll $a$ max. = maximum monthly near-surface chlorophyll $a$ concentration (set to a maximum of $10 \mathrm{mg} / \mathrm{m}^{3}$ ), SSS average = annual average sea surface salinity (SSS, set to a minimum of 30 PSU), PAR max. = maximum monthly photosynthetically active radiation reaching the ocean surface $(\mathrm{PAR})$, SST range $=$ annual SST range, $\mathrm{pH}$ average $=$ annual average $\mathrm{pH}$. Highest Jackknife scores represent largest contributions of environmental variables to explaining geographic distributions of morphotypes, but do not provide information on values of selected environmental variables. 
based on variation in shell shape and size (Figure 3, Table 1). This is one more than was formally described by [25], although he mentioned the existence of two geographic types of C. pacifica. We distinguished three major genetic clades: the Atlantic clade with morphotypes $C$. atlantica and C. cancapae, the Indo-Pacific clade with $C$. columnella, C. urceolaris and C. pacifica $\mathrm{N}$, and the South Pacific clade that consisted entirely of C. pacifica $\mathrm{S}$ (Figure 4). Morphotypes C. atlantica and C. cancapae are endemic to the Atlantic, C. pacifica $\mathrm{N}$ and C. pacifica $\mathrm{S}$ are restricted to the Pacific, and C. columnella and C. urceolaris occur in both the Indian and Pacific oceans (Figure 5). All six morphotypes were clearly disjunct in terms of the combination of shell shape and size, and could be consistently distinguished by LDA. Notably, morphotypes within the same genetic clade were usually the most divergent in morphometric characters. We also found differences in oceanographic habitat preferences, with differences particularly notable within the same genetic clades and ocean basins (see Figures 5, 7 and Additional file 6). In contrast to the terrestrial domain, the application of ecological niche models for depicting ecological tolerances of pelagic taxa has been rare (e.g. $[87,88]$ ). Our ecological niche models have not taken into account diel vertical migration, dispersal limitation and biotic interactions in the prediction of the potential realized niche of the six morphotypes [88]. This may explain why morphotypes were not observed throughout their entire modelled potential niches.

Given the widely documented importance of shell morphology in the adaptation of gastropods (e.g. [89,90]), the phenotypic variation found in Cuvierina taxa may reflect the interplay between genetic adaptation as well as plasticity in response to environmental conditions. For example, at present there is no genetic evidence for concluding that the $C$. atlantica and C. cancapae morphotypes are distinct species. However, genetic differentiation may well be present in other parts of the genome and would be an interesting topic for future research. We hypothesize that interbreeding between C. atlantica and C. cancapae is unlikely given the clearly disjunct morphologies of adult shells congruent with their respective geographic distributions. The preference of $C$. cancapae for warmer waters with lower viscosities may explain its more bottle-shaped morphology with a larger surface to body weight-ratio compared to $C$. atlantica. This could be an adaptation to increase drag and thereby reduce sinking rates in warmer waters [91]. Furthermore, C. cancapae has pronounced shell micro-ornamentation which may also increase drag, whereas C. atlantica shells are completely smooth. All extinct Cuvierina and Ireneia taxa had pronounced shell micro-ornamentation and occurred in warm waters [25], suggesting that micro-ornamentation is the ancestral character state. Common garden studies of other gastropod molluscs have shown that axes of shell shape variation often have a large genetic component, such as in Nucella lapillus $\left(\mathrm{h}^{2}\right.$ of 0.51, [92]) and Littorina saxatilis $\left(\mathrm{h}^{2}\right.$ of 0.35-0.7, [93]).

We tentatively consider interbreeding between morphotypes within the Indo-Pacific clade unlikely as well, pending additional sampling and molecular data. We find clearly disjunct morphologies, extreme size differences and strong ecological preferences of C. urceolaris (warm tropical waters), C. columnella and C. pacifica $\mathrm{N}$ (both in subtropical, oligotrophic gyres) morphotypes. The shell of $C$. urceolaris is bottle-shaped with pronounced micro-ornamentation similar to $C$. cancapae. This may be explained by the same hypothesis as for $C$. cancapae in the Atlantic Ocean, because C. urceolaris also occurs in the warmest waters with lowest viscosities in the Indo-Pacific. Similar to our findings, other studies have reported much stronger phenotypic divergence than (neutral) genetic divergence in marine populations (e.g. [94]), in particular in taxa with high dispersal potential (e.g. [21,95-97]).

Ecological barriers to dispersal and similar distribution patterns as for Cuvierina are found in several other open ocean plankton taxa, such as Diacavolinia pteropods, foraminifers, krill and copepods. Diacavolinia flexipes, $D$. angulosa and D. grayi show a zonation of equatorial and subtropical distribution patterns in the Indian Ocean similar to C. urceolaris and C. columnella distributions [24]. Like C. pacifica S, the krill species Euphausia gibba is endemic to the large South-Pacific gyre [98]. The presence of a disjunct distribution pattern as for $C$. atlantica in the Atlantic Ocean is also observed for the pelagic copepod genus Pleuromamma $[99,100]$ and the mesopelagic copepod Haloptilus longicornis [101]. However, unlike $H$. longicornis, the C. atlantica morphotype is unable to reach the Indian Ocean around South Africa, where a warm current from the Indian Ocean impinges a cold current from the Southern Ocean. Numerous clades of planktonic foraminifers also have distribution patterns that are predominantly based on latitudinal zonation of water masses (e.g. [17]).

Based on results from this study, we do not find support for a subdivision into the subgenera Cuvierina (containing C. atlantica, C. columnella, C. pacifica $\mathrm{N}$ and C. pacifica $S$ ) and the more bottle-shaped Urceolarica (C. urceolaris and C. cancapae) as proposed by $[25,38]$. We find evidence that $C$. pacifica $\mathrm{N}$ and $C$. pacifica $\mathrm{S}$ are distinct species because they belong to different genetic clades (COI and 28S) and are morphologically disjunct. Because the holotype of $C$. pacifica belongs to the C. pacifica S morphotype, we propose a limitation of the description of $C$. pacifica to C. pacifica $\mathrm{S}$ and a new taxonomic description for the C. pacifica $\mathrm{N}$ morphotype (Burridge et al., in prep.). However, because we found no molecular evidence to support the species status of morphotypes within the 
Atlantic and Indo-Pacific clades, we consider it possible that they represent ecophenotypic varieties or incipient species.

\section{Evolution in Cuvierina}

Based on a fossil-calibrated molecular phylogeny, we propose a biogeographic scenario for the evolution of Cuvierina morphotypes that is influenced by decreasing connectivity between the three world oceans since the Miocene (Figure 6). The now extinct ancestral genera Spoelia, Johnjagtia and Ireneia originated during the Oligocene at 34-33 mya as an offshoot of the Creseidae according to [25]. The first Cuvierina was thought to have originated directly from Ireneia [25]. However, the outgroup relationships of Cuvierina remain poorly resolved possibly because ancestral genera, as well as many Miocene and Pliocene Cuvierina taxa, are now extinct (e.g. C. torpedo, C. paronai, C. grandis, C. curryi, C. intermedia, C. jagti, C. inflata, C. ludbrooki, C. astesana, and C. miyakiensis; [25,38,102-104]). There was high connectivity between the three world oceans at the time of divergence between the South Pacific genetic clade and the Atlantic and Indo-Pacific Cuvierina clades at 25.3 (28-23) mya (Late Oligocene), but it is unknown for how long the South Pacific clade has been endemic to the large South Pacific gyre. The divergence between the Atlantic and Indo-Pacific clades of 16.1 (24.5-7) mya (Miocene) coincides with the Tethys Sea closure, suggesting a vicariant model of divergence, with the Indo-Pacific clade diverging from the Atlantic clade in the Indian Ocean and later dispersing to the Pacific basin. Until the Terminal Tethyan Event (TTE, 12-18 mya, [86]), the Atlantic and Indian oceans were connected through the Tethyan Seaway, but pelagic connectivity was probably reduced from \pm 21 mya onwards $[105,106]$. Dispersal between the Atlantic and Pacific oceans was possible until \pm 3.1 mya with the final closure of the Isthmus of Panama (IOP, [86]). However, there are no clear indications of vicariance events of Atlantic and Pacific Cuvierina associated with the IOP (Figure 6). The estimated TMRCAs of the three extant clades correspond very nicely with the estimates based on fossil evidence (5 - 4 mya; [25]).

Connectivity between the three major oceans is now much more restricted at tropical and subtropical latitudes than in the Early Miocene. The Indo-West-Pacific region (IWP) does not seem to represent a physical barrier today, but could have functioned as such between Indian and Pacific populations of C. columnella and $C$. urceolaris during glacial periods when sea levels dropped (e.g. [107]). This is a possible explanation for the subtle morphometric differences between Indian and Pacific $C$. urceolaris and C. columnella specimens. The IWP has also been considered an intermittent barrier to dispersal for several copepods $[99,108]$. In these studies, significant population genetic structuring was found between Indian and Pacific populations of Eucalanus hyalinus and E. spinifer [108] and Pleuromamma xiphias [99].

Physical and ecosystem properties of different Atlantic water masses may be key to incipient speciation within the Atlantic clade. Our population genetic analyses of $C$. atlantica suggest that there is a significant degree of structuring between populations in the northern and southern subtropical gyre systems in the Atlantic Ocean. If genetic structure is interpreted in light of gene flow, this implies a more limited dispersal than expected for open ocean holoplankton. Combined with the disjunct distribution of $C$. atlantica populations, this suggests that the equatorial upwelling waters in the Atlantic represent a significant barrier to dispersal. This equatorial dispersal barrier was also found for the mesopelagic copepod Haloptilus longicornis, for which a genetic break was observed between populations in the northern and southern oligotrophic Atlantic gyres [101]. By contrast, the equatorial Atlantic offers an ecological niche for $C$. cancapae.

\section{Conclusion}

Given the distinct ecological and phenotypic specializations found among both described and undescribed Cuvierina taxa, they may not respond equally to future ocean changes and may not be equally sensitive to ocean acidification. Because the presence and strength of open ocean dispersal barriers depends on the ecological niche of a species, the capacity of a species to adapt to or to track a suitable habitat may vary across closely-related taxa [13]. Although open ocean evolution is partially driven by vicariance, our findings support the view that ecological differentiation may also be a major driving force of speciation for zooplankton.

\section{Availability of supporting data}

The data set supporting the results of this article is available at the Dryad repository, [109], and DNA sequences have been deposited at GenBank under the following accession numbers: KP292620 - KP292794.

\section{Additional files}

\footnotetext{
Additional file 1: Extended summary of Cuvierina samples used in this study.

Additional file 2: Ordination of uncorrected RW data of Cuvierina in an apertural orientation. Fresh $(N=115)$, reference museum $(N=352)$ and other museum specimens $(\mathrm{N}=83)$ are included. Relative Warp 1 explains $56.01 \%$ of the total shape variation; RW2 explains $22.86 \%$. Corresponding thin plate splines of the most positive and negative deformations along the axes are indicated to depict the variation in shell shape. Six distinguished morphotypes are indicated in the legend.
} 
Additional file 3: Maximum likelihood tree of 30 Cuvierina specimens and 6 outgroup taxa using COI (658 bp) and $28 \mathrm{~S}$ (989 bp). Numbers indicate bootstrap support (only bootstrap values of major clades are shown). Symbols for Cuvierina indicate major genetic clades; colours indicate distinct morphotypes (also see Figure 5).

Additional file 4: Pairwise genetic distances within and between Cuvierina morphotypes based on $\mathrm{COI}$ and $28 \mathrm{~S}$.

Additional file 5: Assessment of ecological niche overlap between Cuvierina morphotypes using Schoener's $D$.

Additional file 6: Geographic overview of all Cuvierina specimens used in this study. Sampling locations are projected on a map of annual average sea surface salinities (SSS) (MARSPEC data set, [84]). See legend for explanation of symbols and colours.

\section{Competing interests}

The authors declare that they have no competing interests.

\section{Authors' contributions}

KP and AKB designed the study. AKB generated and analysed the geometric morphometric data and DNA sequences. NR and AKB applied ecological niche modelling. AKB and KP wrote the paper. KP, EG, NR and JH provided intellectual input. All authors read and approved the submission.

\section{Acknowledgements}

We are grateful to A.W. Janssen for his ideas, inspiration for this research, and many articles on pteropod fossils. We are indebted to H. Miyamoto, A. Tsuda and R.A. Gasca Serrano who generously provided freshly collected Cuvierina samples from diverse regions in the world. We thank J. van Arkel for his assistance concerning specimen photography, to P. Meirmans for his introduction to statistical analyses in R, to V. Merckx for his advice on phylogenetic methods and to L. Dong, B. Voetdijk, and P. Kuperus for technical assistance in the IBED molecular lab. Finally, we thank P. Tarroso, A.W. Janssen, S.B.J. Menken, B.W. Hoeksema and the anonymous reviewers for their helpful comments on this manuscript, and W. Renema, E. Michel, J. Todd, Y. Young and O.S. Tendal for insightful discussions and inspiration. This study was partially supported by the UK Natural Environment Research Council National Capability funding to Plymouth Marine Laboratory and the National Oceanography Centre, Southampton. This is contribution number 264 of the AMT programme. AKB was supported by The Malacological Society of London Research grant, NR by the Netherlands Research Council NWO-ALW grant 819.01.014, EG by NSF grants OCE-1029478 and OCE-1338959, and KP by SYNTHESYS grant DK-TAF-5199 and NWO-VENI grant 863.08.024.

\section{Author details}

${ }^{1}$ Naturalis Biodiversity Center, P.O. Box 9517, Leiden 2300 RA, The Netherlands. ${ }^{2}$ Institute for Biodiversity and Ecosystem Dynamics (IBED), University of Amsterdam, P.O. Box 94248, Amsterdam 1090 GE, The Netherlands. ${ }^{3}$ Department of Oceanography, University of Hawaii at Manoa, 1000 Pope Road, Honolulu, HI 96822, USA.

Received: 1 July 2014 Accepted: 19 February 2015

Published online: 12 March 2015

\section{References}

1. Jörger KM, Stöger I, Kano Y, Fukuda H. On the origin of Acochlida and other enigmatic euthyneuran gastropods, with implications for the systematics of Heterobranchia. BMC Evol Biol. 2010;10:323. doi:10.1186/1471-2148-10-323.

2. Fabry VJ, Seibel BA, Feely RA, Orr JC. Impacts of ocean acidification on marine fauna and ecosystem processes. ICES J Mar Sci. 2008;65:414-32.

3. Feely RA, Sabine CL, Lee K, Berelson W, Kleypas J, Fabry VJ, et al. Impact of anthropogenic $\mathrm{CO}_{2}$ on the $\mathrm{CaCO}_{3}$ system in the oceans. Science. 2004;305:362-6.

4. Orr JC, Fabry VJ, Aumont O, Bopp L, Doney SC, Feely RA, et al. Anthropogenic ocean acidification over the twenty-first century and its impact on calcifying organisms. Nature. 2005;437:681-6.

5. Bednaršek N, Tarling GA, Bakker DCE, Fielding S, Jones EM, Venables HJ, et al. Extensive dissolution of live pteropods in the Southern ocean. Nat Geosci. 2012;5:881-5.
6. Bednaršek N, Feely RA, Reum JCP, Peterson B, Menkel J, Alin SR, et al. Limacina helicina shell dissolution as an indicator of declining habitat suitability owing to ocean acidification in the California Current Ecosystem. Proc R Soc B. 2014;281:20140123.

7. Comeau S, Gattuso JP, Nisumaa AM, Orr J. Impact of aragonite saturation state changes on migratory pteropods. Proc R Soc B. 2012;279:732-8.

8. Roger LM, Richardson AJ, McKinnon AD, Knott B, Matear R, Scadding C. Comparison of the shell structure of two tropical Thecosomata (Creseis acicula and Diacavolinia longirostris) from 1963 to 2009: potential implications for declining aragonite saturation. ICES J Mar Sci: J du Conseil. 2011;69(3):465-74.

9. Janssen AW, Peijnenburg KTCA. Holoplanktonic Mollusca: development in the Mediterranean basin during the last 30 million years and their future. In: Goffredo S, Dubinsky Z, editors. The Mediterranean sea: its history and present challenges. Dordrecht: Springer; 2013. p. 341-62.

10. Lalli CM, Gilmer RW. The thecosomes. Shelled pteropods. In: Lalli CM, Gilmer RW, editors. Pelagic snails. The biology of holoplanktonic gastropod molluscs. California: Stanford University Press; 1989. p. 58-166.

11. Jin P, Gao K, Beardall J. Evolutionary responses of a coccolithophorid Gephyrocapsa oceanica to ocean acidification. Evolution. 2013;67(7):1869-78.

12. Lohbeck KT, Riebesell U, Collins S, Reusch TBH. Functional genetic divergence in high $\mathrm{CO}_{2}$ adapted Emiliana huxleyi populations. Evolution. 2012;67(7):1892-900.

13. Peijnenburg KTCA, Goetze E. High evolutionary potential of marine zooplankton. Ecol Evol. 2013;3(8):2765-81

14. Sa'ez AG, Probert I, Gelsen M, Quinn P, Young JR, Medlin LK. Pseudo-cryptic speciation in coccolithophores. Proc Natl Acad Sci U S A. 2003;100(12):7163-8.

15. De Vargas C, Zaez AG, Medlin LK, Thierstein HR. Super-species in the calcareous plankton. In: Thierstein HR, Young YR, editors. Coccolithophores: from molecular processes to global impact. Berlin: Springer; 2004. p. 271-98.

16. Aurahs $\mathrm{R}$, Treis $\mathrm{Y}$, Darling K, Kucera M. A revised taxonomic and phylogenetic concept for the planktonic foraminifer species Globigerinoides ruber based on molecular and morphometric evidence. Mar Micropaleontol. 2011;79:1-14.

17. Darling KF, Wade CM. The genetic diversity of planktic foraminifera and the global distribution of ribosomal RNA genotypes. Mar Micropaleontol. 2008;67:216-38.

18. Seears HA, Darling KF, Wade CM. Ecological partitioning and diversity in tropical planktonic foraminifera. BMC Evol Biol. 2012;12:54. doi:10.1186/ 1471-2148-12-54.

19. Ujiié Y, Asami T, De Garidel-Thoron T, Liu H, Ishitani Y, De Vargas C. Longitudinal differentiation among pelagic populations in a planktic foraminifer. Ecol Evol. 2012;2(7):1725-37.

20. Weiner A, Aurahs R, Kurasawa A, Kitazaho H, Kucera M. Vertical niche partitioning between cryptic sibling species of a cosmopolitan marine planktonic protist. Mol Ecol. 2012;21:4063-73.

21. Luttikhuizen PC, Drent J, Van Delden W, Piersma T. Spatially structured genetic variation in a broadcast spawning bivalve: quantitative vs. molecular traits. J Evol Biol. 2003;16:260-72.

22. Phillips SJ, Anderson RP, Schapire RE. Maximum entropy modelling of species geographic distributions. Ecol Model. 2006;190:231-59.

23. Van der Spoel S. Euthecosomata, a group with remarkable developmental stages (Gastropoda, Pteropoda), PhD thesis. Amsterdam: University of Amsterdam; 1967.

24. Van der Spoel S, Bleeker J, Kobayasi H. From Cavolinia longirostris to twenty-four diacavolinia taxa, with a phylogenetic discussion (Mollusca, Gastropoda). Bijdr Dierk. 1993;62(3):127-66.

25. Janssen AW. Development of Cuvierinidae (Mollusca, Euthecosomata, Cavolinioidea) during the Cainozoic: a non-cladistic approach with a re-interpretation of Recent taxa. Basteria. 2005;69:25-72.

26. Van der Spoel S. Morphometric data on Cavoliniidae, with notes on a new form of Cuvierina columnella (Rang, 1827) (Gastropoda, Pteropoda). Basteria. 1970;34(5-6):103-51.

27. Van der Spoel S. Geographical variation in Cavolinia tridentata (Mollusca, Pteropoda). Bijdr Dierk. 1974;44(1):100-12.

28. Aiello G, Barratolo F, Barra D, Fiorito G, Mazzarella A, Raia P, et al. Fractal analysis of ostracod shell variability: a comparison with geometric and classic morphohometrics. Acta Palaeontol Pol. 2007;52(3):563-73.

29. Klingenberg CP. Evolution and development of shape: integrating quantitative approaches. Nat Rev. 2010;11:623-35. 
30. Mitteroecker P, Gunz P. Advances in geometric morphometrics. Evol Biol. 2009;36:235-47.

31. Corse E, Rampal J, Cuoc C, Peck N, Perez Y, Gilles A. Phylogenetic analysis of Thecosomata Blainville, 1824 (Holoplanktonic Opisthobranchia) using morphological and molecular data. PLoS One. 2013;8(4):e59439.

32. Jennings RM, Bucklin A, Ossenbrüger $H$, Hopcroft RR. Species diversity of planktonic gastropods (Pteropoda and Heteropoda) from six ocean regions based on DNA barcode analysis. Deep-Sea Res II. 2010; 57(24-26):2199-210.

33. Klussman-Kolb A, Dinapoli A. Systematic position of the pelagic Thecosomata and Gymnosomata within Opisthobranchia (Mollusca, Gastropoda) - revival of the Pteropoda. J Zool Syst. 2006;44(2):118-29.

34. Maas AE, Blanco-Bercial L, Lawson GL. Reexamination of the species assignment of Diacavolinia pteropods using DNA barcoding. PLoS One. 2013;8(1):e53889. doi:10.1371/journal.pone.0053889.

35. Gasca R, Janssen AW. Taxonomic review, molecular data and key to the species of Creseidae from the Atlantic Ocean. J Mollus Stud. 2014;80:35-42. doi:10.1093/mollus/eyt038.

36. Bé AWH, MacClintock C, Currie DC. Helical shell structure and growth of the pteropod Cuvierina Columnella (Rang) (Mollusca, Gastropoda). Biomineral Res Reps. 1972:4:47-79.

37. Bé AWH, Gilmer RW. A zoogeographic and taxonomic review of Euthecosomatous Pteropoda. In: Ramsay ATS, editor. Oceanic micropalaeontology. Volume 1. London: Academic; 1977. p. 733-800.

38. Janssen AW. Notes on systematics, morphology and biostratigraphy of fossil holoplanktonic Mollusca. Some additional notes and amendments on Cuvierinidae and on classification of Thecosomata (Mollusca, Euthecosomata). Basteria. 2006;70:67-70.

39. Mörch OAL. Catalogus Conchyliorum quae reliquit C.P. Kierulf, Md. Dr., nunc Publica Auctione X Decembris MDCCCL Hafniae Dividenda. Typis Trieri, Hafniae; 1850.

40. Rang PCAL. Description de deux genres nouveaux (Cuvierina et Euribia) appartenant à la classe des pteropodes. Ann Sci Nat. 1827;12:320-9.

41. Bednaršek N, Možina J, Vogt M, O'Brien C, Tarling GA. The global distribution of pteropods and their contribution to carbonate and carbon biomass in the modern ocean. Earth Syst Sci Data. 2012:4:167-86.

42. McManus GB, Katz LA. Molecular and morphological methods for identifying plankton: what makes a successful marriage? J Plankton Res. 2009;31:1119-29.

43. Van Couwelaar M. Pelagic faunas in monsoon ruled seas, PhD thesis. Amsterdam: University of Amsterdam; 1998.

44. Gibbs RH. Cruise report on ACRE 12, RN Delaware II. 1971.

45. Gibbs RH, Roper CFE, Brown DW, Goodyear RW. Biological studies of the Bermuda Ocean ACRE I. Station data, methods and equipment for cruises 1 through 11, October 1967 - January 1971. Report to the U.S. Navy Underwater Systems Center; 1971

46. Krueger WH, Gibbs RH, Kleckner RC, Keller AA, Keene MJ. Distribution and abundance of mesopelagic fishes on cruises 2 and 3 at Deepwater Dumpsite 106. Includes appendix table with station data from cruises 1-4. Cruise report. Washington: University of Rhode Island, Kingston, and National Museum of Natural History, Smithsonian Institution; 1976.

47. Schmidt J. Dana-Report Vol. I 1932-1934: the carlsberg foundation's oceanographical expedition round the world 1928-1939, and previous 'Dana' expeditions. Copenhagen: C.A. Reitzels Forlag; London: Oxford University Press; 1934

48. Rohlf FJ. Tps series. 2006. [http://life.bio.sunysb.edu/morph]

49. Gunz P, Mitteroecker P. Semilandmarks: a method for quantifying curves and surfaces. It J Mamm. 2013;24(1):103-9.

50. Kendall D. The diffusion of shape. Adv Appl Probabl. 1977;9:428-30.

51. Zelditch ML, Swiderski DL, Sheets HD, Fink WL. Geometric morphometrics for biologists. San Diego and London: Elsevier Academic Press; 2004.

52. Hammer $\varnothing$, Harper DAT, Ryan PD. PAST: paleontological statistics software package for education and data analysis. Palaeontol Electron. 2001:4(1):1-9.

53. R development Core Team R. A language and environment for statistical computing. 2013. [http://www.R-project.org]

54. Anderson MJ. A new method for non-parametric multivariate analysis of variance. Austral Ecol. 2001:26:32-46.

55. Holland PWH. Cloning genes using the polymerase chain reaction. In: Stern CD, Holland PWH, editors. Developmental biology: a practical approach. Oxford: Oxford University Press; 1993. p. 243-55.
56. Folmer O, Black M, Hoeh W, Lutz R, Vrijenhoek R. DNA primers for amplification of mitochondrial Cytochrome c Oxidase subunit I from diverse metazoan invertebrates. Mol Mar Biol Biotechnol. 1994;3(5):294-9.

57. Dayrat B, Tillier A, Lecointre G, Tillier S. New clades of Euthyneuran Gastropods (Mollusca) from 28S rRNA sequences. Mol Phylogenet Evol. 2001;19(2):225-35

58. Altschul SF, Madden TL, Schäfer AA, Zhang J, Zhang Z, Miller W, et al. Gapped BLAST and PSI-BLAST: a new generation of protein database search programs. Nucleic Acids Res. 1997;25:3389-402.

59. Felsenstein J. Evolutionary trees from DNA sequences: a maximum likelihood approach. J Mol Ecol. 1981;17:368-76.

60. Silvestro D, Michalak I. RaxmIGUI: a graphical front-end for RAxML. Org Divers Evol. 2012;12:335-7.

61. Stamatakis A. RAXML-VI-HPS: maximum likelihood-based phylogenetic analyses with thousands of taxa and mixed models. Bioinformatics. 2006;22(21):2688-90

62. Darriba D, Taboada GL, Doallo R, Posada D. jModelTest 2: more models, new heuristics and parallel computing. Nat Methods. 2012;9(8):772.

63. Shapiro B, Rambaut A, Drummond AJ. Choosing appropriate substitution models for the phylogenetic analysis of protein-coding sequences. Mol Biol Evol. 2006;23(1):7-9.

64. Tamura K, Stecher G, Peterson D, Filipski A, Kumar S. MEGA6: molecular evolutionary genetics analysis version 6.0. Mol Biol Evol. 2013;30(12):2725-19.

65. Stephens M, Donelly P. A comparison of Bayesian methods for haplotype reconstruction from population genotype data. Am J Hum Genet. 2003;73:1162-9.

66. Stephens M, Smith N, Donelly P. A new statistical method for haplotype reconstruction from population data. Am J Hum Genet. 2001;68:978-89.

67. Librado P, Rozas J. DnaSP v5: a software for comprehensive analysis of DNA polymorphism data. Bioinformatics. 2009;25:1451-2.

68. Nei M. Molecular evolutionary genetics. New York: Columbia University Press; 1987.

69. Tajima F. Evolutionary relationship of DNA sequences in finite populations. Genetics. 1983;105:437-60

70. Excoffier L, Laval G, Schneider S. Arlequin ver, 3.0: an integrated software package for population genetics and data analysis. Evol Bioinform Online. 2005;1:47-50.

71. Rice WR. Analyzing tables of statistical tests. Evolution. 1989:43(1):223-5.

72. Drummond AJ, Suchard MA, Xie D, Rambaut A. Bayesian phylogenetics with BEAUti and the BEAST 1.7. Mol Biol Evol. 2012;29(8):1969-73.

73. Rambaut A, Drummond AJ. Tracer v1.5. 2009. [http://beast.bio.ed.ac.uk/Tracer]

74. Gernhard T. The conditioned restructured process. J Theor Biol. 2008:253:769-78

75. Wenz W. Gastropoda extramarina tertiaria, 5. Animalia. Fossilium Catalogus 1923:22:1421-734

76. Janssen AW. Notes on the systematics, morphology and biostratigraphy of fossil holoplanktonic mollusca, 17. On the status of some pteropods (Gastropoda, Euthecosomata) from the Miocene of New Zealand, referred to as species of Vaginella. Basteria. 2006;70:71-83.

77. Tyberghein L, Verbruggen H, Pauly K, Troupin C, Mineur F, De Clerck O. Bio-ORACLE: a global environmental dataset for marine species distribution modelling. Glob Ecol Biogeogr. 2012;21:272-81.

78. Dormann CF, Elith J, Bacher S, Buchmann C, Carl G, Carré G, et al. Collinearity: a review of methods to deal with it and a simulation study evaluating their performance. Ecography. 2013;36:27-46.

79. Elith J, Phillips SJ, Hastie T, Dudik M, En Shee Y, Yates CJ. A statistical explanation of maxent for ecologists. Diversity Distrib. 2011:17:43-57.

80. Raes N, Ter Steege H. A null-model for significance testing of presence-only species distribution models. Ecography. 2007;30:727-36

81. Schoener TW. The Anolis lizards of Bimini: resource partitioning in a complex fauna. Ecology. 1968;49:704-26.

82. Warren DL, Glor RE, Turelli M. Environmental niche equivalency versus conservatism: quantitative approaches to niche evolution. Evolution. 2008;62:2868-83

83. Warren DL, Glor RE, Turelli M. ENMTools: a toolbox for comparative studies of environmental niche models. Ecography. 2010;33:607-11.

84. Sbrocco EJ, Barber PH. MARSPEC: ocean climate layers for marine spatial ecology. Ecology. 2013:94(4):979.

85. Cahuzak B, Janssen AW. Eocene to miocene holoplanktonic Mollusca (Gastropoda) of the Aquitane basin, southwest France. Scripta Geol. 2010;141:1-193. 
86. Cowman PF, Bellwood DR. Vicariance across major marine biogeographic barriers: temporal concordance and the relative intensity of hard versus soft barriers. Proc R Soc B. 2013;280:20131541. doi: 10.1098/rspb.2013.1541.

87. Provan J, Beatty GE, Keating SL, Maggs CA, Savidge G. High dispersal potential has maintained long-term population stability in the North Atlantic copepod Calanus finmarchicus. Proc R Soc B. 2009;276:301-7.

88. Robinson LM, Elith J, Hobday AJ, Pearson RG, Kendall BE, Possingham HP. Pushing the limits in marine species distribution modelling: lessons from the land present challenges and opportunities. Glob Ecol Biogeogr. 2011:20:789-802

89. Rolán-Alvarez E, Carballo M, Galindo J, Morán P, Fernández B, Caballero A, et al. Nonallopatric and parallel origin of local reproductive barriers between two snail ecotypes. Mol Ecol. 2004;13:3415-24.

90. Vermeij GJ. Characters in context: molluscan shells and the forces that mold them. Paleobiol. 2002;28:41-54.

91. Power JH. Sink or swim: growth dynamics and zooplankton hydromechanics. Am Nat. 1989;133:706-21.

92. Colson I, Guerra-Valela J, Hughes RN, Rolán-Alvarez E. Using molecular and quantitative variation for assessing genetic impacts on Nucella lapillus populations after local extinction and recolonization. Integr Zool. 2006;1:104-7.

93. Conde-Padin P, Carvajal-Rodriquez A, Carballo M, Caballero A, Rolán-Alvarez E. Genetic variation for shell traits in a direct-developing marine snail involved in a putative sympatric ecological speciation process. Evol Ecol. 2007:21:635-50.

94. Mariani S, Peijnenburg KTCA, Weetman D. Independence of neutral and adaptive divergence in a low dispersal marine mollusc. Mar Ecol Prog Ser. 2012:446:173-87.

95. André C, Larsson LC, Laikre L, Bekkevold D, Brigham J, Carvalho CR, et al. Detecting population structure in a high gene flow species, Atlantic herring (Clupea harengus): direct, simultaneous evaluation of neutral vs. putatively selected loci. Heredity. 2011;106:270-80.

96. Hollander J. Testing the grain-size model for the evolution of phenotypic plasticity. Evolution. 2008;62(6):1381-9.

97. Yebra L, Bonnet D, Harris RP, Lindeque P, Peijnenburg KTCA. Barriers in the pelagic: population structuring of Calanus helgolandicus and C. euxinus in European waters. Mar Ecol Prog Ser. 2011;428:135-49.

98. Van der Spoel S, Heyman RP. A comparative atlas of zooplankton: biological patterns in the oceans. New York: Springer; 1983.

99. Goetze E. Population differentiation in the open sea: insights from the pelagic copepod pleuromamma xiphias. Integr Comp Biol. 2011;51:580-97.

100. Halbert KMK, Goetze E, Carlon DB. High cryptic diversity across the global range of the migratory planktonic copepods Pleuromamma piseki and $\mathrm{P}$. gracilis. PLoS One. 2013;8(10):e77011.

101. Norton E, Goetze E. Equatorial dispersal barriers and limited population connectivity among oceans in a planktonic copepod. Limnol Oceanogr. 2013;58(5):1581-96.

102. Janssen AW. Notes on the systematics, morphology and biostratigraphy of fossil holoplanktonic Mollusca. On the status of Cuvierina (Cuvierina) ludbrooki and C. (C.) jagti (Gastropoda, Euthecosomata). Basteria. 2006;70:85-8.

103. Janssen AW. Holoplanktonic Mollusca (Gastropoda: Pterotracheoidea, Janthinoidea, Thecosomata and Gymnosomata) from the Pliocene of Pangasinan (Luzon, Philippines). Scripta Geol. 2007;135:29-177.

104. Janssen AW. Late Quaternary to recent holoplanktonic Mollusca (Gastropoda) from bottom samples of the eastern Mediterranean Sea: systematics, morphology. Boll Malacol. 2012:48:1-105.

105. Harzhauser M, Piller WE, Steiniger FF. Circum-mediterranean oligo-miocene biogeographic evolution - the gastropod's point of view. Palaeogeogr Palaeoclimatol Palaeoecol. 2002;183:103-33.

106. Harzhauser M, Kroh A, Mandic O, Piller WE, Göhlich U, Reuter M, et al. Biogeographic responses to geodynamics: a key study all around the oligo-miocene tethyan seaway. Zool Anz. 2007;246:241-56.
107. Gaither MR, Toonen RJ, Robertson DR, Planes S, Bowen BW. Genetic evaluation of marine biogeographical barriers: perspectives from two widespread Indo-Pacific snappers (Lutjanus kasmira and Lutjanus fulvus). J Biogeogr. 2010;37:133-47.

108. Goetze E. Global population genetic structure and biogeography of the oceanic copepods Eucalanus hyalinus and E. spinifer. Evolution. 2005;59:2378-98

109. Burridge AK, Goetze E, Raes N, Huisman J, Peijnenburg KTCA. Data from: global c. BMC Evol Biol. 2015. doi:10.5061/dryad.7n1q4.

\section{Submit your next manuscript to BioMed Central and take full advantage of:}

- Convenient online submission

- Thorough peer review

- No space constraints or color figure charges

- Immediate publication on acceptance

- Inclusion in PubMed, CAS, Scopus and Google Scholar

- Research which is freely available for redistribution 